\title{
Growth, Protein Content, Yield and Yield Components of Malt Barley (Hordeum vulgare L.) Varieties in Response to Seeding Rate at Sinana District, Southeast Ethiopia
}

\author{
Senait Bekele ${ }^{1}$, Tarekegn Yoseph ${ }^{2}$, Tewodros Ayalew ${ }^{2}$ \\ ${ }^{1}$ Oromia Seed Enterprise, Bale Branch, Bale-Robe, Ethiopia \\ ${ }^{2}$ Schools of Plant and Horticulture Sciences, College of Agriculture, Hawassa University, Hawassa, Ethiopia \\ Email address: \\ senibekele1@gmail.com (S. Bekele), tareyoseph@gmail.com (T. Yoseph), tedy130@yahoo.com (T. Ayalew) \\ To cite this article: \\ Senait Bekele, Tarekegn Yoseph, Tewodros Ayalew. Growth, Protein Content, Yield and Yield Components of Malt Barley (Hordeum vulgare \\ L.) Varieties in Response to Seeding Rate at Sinana District, Southeast Ethiopia. International Journal of Applied Agricultural Sciences. \\ Vol. 6, No. 4, 2020, pp. 61-71. doi: 10.11648/j.ijaas.20200604.12
}

Received: March 20, 2020; Accepted: April 28, 2020; Published: June 20, 2020

\begin{abstract}
Identifying optimum seeding rate for crop varieties is an important agronomic practice to improve the productivity and the quality of the produces. Therefore, this study was conducted to evaluate the effect of seeding rate on the growth, protein content and yield performance of malt barley varieties grown under rain-fed conditions at Sinnana district, southeast Ethiopia. The treatments studied include five malt barley varieties (Singitan, Bahati, IBON174/3, HB - 1964 and Holker) and four seed rates $\left(100,125,150\right.$, and $\left.175 \mathrm{~kg} \mathrm{ha}^{-1}\right)$. The experiments were arranged using factorial randomized complete block design with three replicates. The results revealed significant differences among the varieties and seeding rates for days to $50 \%$ heading, $90 \%$ physiological maturity, plant height, productive tiller $\left(\mathrm{m}^{2}\right), 1000$-kernel weight, grain protein content and grain yield $\left(\mathrm{kg} \mathrm{ha}^{-1}\right)$. Among the barely varieties, Holker recorded the longest days to $50 \%$ heading ( 75.0 days) and plant height $(91.79 \mathrm{~cm})$. The heavier 1000-kernel weight was produced from Singitan and Bahati $(43.52 \mathrm{gm})$ and $(43.30 \mathrm{gm})$ varieties, respectively. Increment in seed rate from $100-175 \mathrm{~kg} \mathrm{ha}^{-1}$ decreased days to $50 \%$ heading by $6 \%$ and thousand kernels weight by $23.51 \%$. Furthermore, the interaction effect of variety and seeding rate showed significant differences on productive tiller, harvest index, grain protein content and grain yield. The use of $150 \mathrm{~kg} \mathrm{ha}^{-1}$ seed rate for variety Singitan resulted in higher number of productive tillers $\left(1017.33\right.$ per $\left.\mathrm{m}^{2}\right)$, thousand kernels weight $(43.52 \mathrm{~g})$, grain yield $\left(3.63 \mathrm{t} \mathrm{ha}^{-1}\right)$, Hectoliter weight $\left(62.98 \mathrm{~kg} \mathrm{ha}^{-1}\right)$ and lower protein content $(10.7 \%)$. As per the result of the partial budget analysis, higher benefit also recorded from the use of variety Singitan with a seed rate of $150 \mathrm{~kg} \mathrm{ha}^{-1}$. From the results of this study it can be concluded that, better crop performance, higher grain yield and economic return achieved from the combinations of variety Singitan, Bahati and HB1964 with a seed rate of $150 \mathrm{~kg} \mathrm{ha}^{-1}$ and variety IBON174/3 and Holker with seed rate of $125 \mathrm{~kg} \mathrm{ha}^{-1}$.
\end{abstract}

Keywords: Protein Content, Seed Rate, Thousand-kernel Weight, Varieties and Yield

\section{Introduction}

Barley (Hordeum vulgare L.) is one of the major cereal crops that are largely produced in the central and southeast mid- and high-altitudes of Ethiopia. It is the fifth most important cereal crop after tef, maize, wheat and sorghum [16]. It is cultivated in almost all regions of the country having an altitude ranging from 1,400-over 4,000 meters above sea level. It is the most desirable crop in the highlands where there is a limited alternative crop [69].

The two commonly cultivated types in Ethiopia include food and malt barley. Traditionally it is used for making local recipes and drinks such as 'dabo', 'kolo', 'ganfo', 'kinche', 'baso,' tela', 'borde' and other types of food. It is one of the main sources of calories [69] The use of naked barley roasted grain as 'kolo' for consumption has a traditional background providing blood glucose stabilization, cardiovascular protection, and cancer prevention. This ancient grain satisfies more than just the palate [38]. Similar to other food grains, barely has gained popularity and regarded as "poor man's bread". Thus, the current consumer interest regarding its nutrition and health benefits are expected to improve more its 
production status as a human diet [50].

Malt barley is the basic raw material for brewing. Its chemical composition affects the beer quality and the economic efficiency of the brewing process [57]. The malt barley grain should meet the following standards.

It should be fully mature and plump with high kernel weight, low protein content of $9-11.5 \%$ on dry matter basis, high germination capacity of over $95 \%$, moisture level of less than $12 \%$, and uniform size and shape. In addition, colure of the grain must be uniform and bright, the smell should be fresh and not musty or earthy, and the husk should be fine and wrinkled rather than coarse and stretched. Foreign seeds, weeds and other impurities should be kept under 0.5\% [40]. The reason plumpness is so important is that maltsters wanted to produce more extract, which means more beer [18]. The texture of endosperm influences the malt modification process by affecting water uptake and enzyme synthesis within the endosperm [12].

Malt barley is considered as one of the cash crops and its demand by malt factory has increased due to its increased capacity of processing and the expansion of breweries and beer consumption levels in the country [5]. However, only about $35-40 \%$ of the industrial demands supplied from domestic production and the remaining quantity is imported from abroad by foreign currency [22]. In spite of the importance of barley as a food and malting crop, the efforts made so far to generate improved production technologies and its productivity has remained low. For instance, its average national yield is about $1.97 \mathrm{t} \mathrm{ha}^{-1}$, which is low compared to the world average of $3.1 \mathrm{tha}^{-1}$ [23]. The low yield of barley is partly attributed to cultivation of unimproved low yielding varieties, low level of soil nutrient contents particularly nitrogen $(\mathrm{N})$ and phosphorus $(\mathrm{P})$, lack of appropriate seeding rate, the influence of several biotic and a biotic stress and the minimal promotion of improved barley production technologies [31].

Among the agronomic practices, using optimum seeding rate is one of the most important factors to maximize productivity and improve the qualities required for malting purpose. For instance, if more seed rate is used, plant population will be more and there will be competition among plants for water, nutrients and sunlight resulting in low quality and low yield. On the other hands, when low seed rate is used yield will be lower due to lesser number of plants per unit area [29]. Therefore, to alleviate these constraints and exploit the genetic yield potential of barley more effort is needed among others, assessing them under different agronomic practices. The research results indicated that, barley yields were close to maximum at seeding rates of 81 to $108 \mathrm{~kg} \mathrm{ha}^{-1}$, but maximum yields were generally obtained at the highest seeding rate of $161 \mathrm{~kg} \mathrm{ha}^{1}$ [27, 63] Indicated that the crop plants should cover the soil as early as possible to intercept maximum sunlight to produce higher dry matter as the intercepted solar radiation and dry matter production are directly related to each other.

Plumpness is one of the important factors to be considered in selecting barley variety for malt purpose. Using appropriate seeding rate was reported to improve such characteristics and modify starch and protein levels of the seed [54]. Optimum seeding rate resulted in more uniformity of barley kernels, which improves the modification process and produces higher quality malt. According to [53] optimum seeding rate also reduces beta-glucan levels while friability and homogeneity was improved all positive factors for maltsters. Kernel weight declines with increasing seeding rate and which in turn reduce malt acceptability [43]. Therefore, an urgent need to identify optimum seeding rate and improved barley varieties in order to improve its yield and grain quality for malt barley.

Stability of grain yield performance across a growing season is an important characteristic in the selecting a new crop varieties [15]. Accordingly, yield related parameters such as: productive tillers per plant, number of kernels per spike and 1000 kernel weight are more useful criteria for selecting evolving high yield varieties due to their high heritability values and direct effect on grain yield $[34,25]$ Also indicated that the genetic effect on grain size had greater impact than environmental effect, even when the environment suffered from terminal moisture stress, with a heritability value of $89-98 \%$ for plump grains. Varieties with higher kernel weight with plump grains + will have more starch accumulated in the endosperm and hence will have more malt extract which will help to make good beer [21].

Barley varieties had significant effect on growth, yield and protein quality related parameters [3]. Days to heading, days to maturity, spike length, plant height, 1000-kernel weight and grain yield were markedly affected by the varieties [37]. The yield and quality specifications of a given variety are also determined by its genetic makeup and the physical conditions during growth [28]. Similarly, [4] reported a marked different among the malt barely varieties on grain size and kernel weight due to genotypic variation. The varieties also showed a consistent difference in grain protein content due to the genetic makeup and growing environmental condition [48].

In Ethiopia including the study area, however, the same seeding rate recommendations are generally made for all varieties under commercial production. However, such recommendation on seeding rate is not addressing the required optimum yield and quality of the malting barley varieties and hence need to be custom tailored. However, little is known as to what the varietal differences will have on seeding rates and their interaction effects to optimize malt barley quality and quantity in bale highlands. Therefore, this study was to evaluate the effect of seeding rates on the performance of malt barley varieties grown under rain-fed conditions

\section{Materials and Methods}

\subsection{Description of the Study Area}

Afield experiment was conducted at Sinana Agricultural Research Centre in 2018 main cropping season. SARC is 
located $7^{\circ} 7^{\prime} \mathrm{N}$ latitude and $40^{\circ} 0^{\prime}$ E longitude in Bale Zone of Oromia Regional State. It is found at a distance of $463 \mathrm{~km}$ southeast of Addis Ababa Ethiopia and $33 \mathrm{~km}$ east of Robe town (capital city of the Bale Zone) on the road to Goro and Sofumar cave. The site is located at an altitude of $2400 \mathrm{~m}$. above sea levels. The area is characterized by bimodal rainfall pattern. There are two growing seasons locally called 'Bona' and Gana' based on the time of crop harvest. Bona extends from August to December and Gana from March to July. The mean annual rainfall of $750-1000 \mathrm{~mm}$ and mean annual temperature of $9-21^{\circ} \mathrm{C}$ and the soil of the area is dominated by Cambi soil [52].

\subsection{Experimental Design and Procedures}

The experiment was arranged in a Randomized Complete Block Design (RCBD) in factorial combination with three replications. The treatments studied include four seeding rates $\left(100,125,150\right.$ and $\left.175 \mathrm{~kg} \mathrm{ha}^{-1}\right)$ and five barely (Singitan, Bahati, IBON-174/03, Holker and HB1964) varieties. Thus, the experiment consists of 20 treatments with a total of 60 plots. The size of each plot was $(3 \mathrm{mx}$ $2.4 \mathrm{~m}=7.2 \mathrm{~m}^{2}$ ) and the spacing between rows, plots and blocks were $0.2,0.5$ and $1 \mathrm{~m}$, respectively. There were 12 rows in a plot and planting was done by hand in the rows and covered with soil manually. $\mathrm{N}$ and $\mathrm{P}$ fertilizers which are sourced from UREA and NPS were applied equally for all plots at the recommended rate of 50 and $69 \mathrm{~kg}_{2} \mathrm{O}_{5} \mathrm{ha}^{-1}$, respectively. Barley yellow dwarf virus was scored based on visual field symptoms by visual scoring scale system regardless of the BYDV strain or species responsible [17]. All recommended agronomic practices were applied throughout the growth period.

\section{Data collected and measurements}

Days to heading: Days to heading was recorded when about $50 \%$ of the plants in plot-produced spikes.

Days to maturity: Days to maturity was recorded when about $90 \%$ of the plants reached physiological maturity.

Plant height $(\mathrm{cm})$ : It was measured at physiological maturity from the soil surface to the top of the spike (awns excluded) from 5 randomly selected plants in the central harvestable row.

Spike length $(\mathrm{cm})$ : This was measured from the bottom of the spike to the tip of the spike excluding the awns from 5 randomly selected spikes from each plot.

Number of productive tiller $\left(\mathrm{m}^{-2}\right)$ : This was determined by counting all the spikes producing seeds in $1 \mathrm{~m}^{2}$ taken randomly from two places in each net plot area.

$\mathrm{Kernels} \mathrm{spike}^{-1}$ : It was determined by counting the number of kernels per spike from randomly selected five spikes per plot from harvestable rows.

Thousand kernels weight $(\mathrm{g})$ : thousand seeds was counted using seed counter and measured in gram to calculate the weight.

Above ground biomass yield $\left(\mathrm{t} \mathrm{ha}^{-1}\right)$ : This was determined as the weight in $\mathrm{tha}^{-1}$ of sun-dried above ground parts of the plants that was obtained from harvestable rows.

Grain yield $\left(\mathrm{t} \mathrm{ha}^{-1}\right)$ : It was determined at physiological maturity from the harvestable ten rows and converted in to $t$ $\mathrm{ha}^{-1}$ after adjusting it at $12 \%$ moisture content.

Harvest Index (\%): It was calculated as the ratio of grain yield to total above ground biomass yield.

Barley yellow dwarf virus: was scored based on visual field symptoms by visual scoring scale system scale from 0 9

Grain Protein content Protein content was determined by whole grain analysis using Near Infrared Spectroscope Analyser (MininfraSmarT SW® Whole Grain Analyser, H2013 Pomáz, and Budakalásziút7. Hungary).

\subsection{Statistical Data Analysis}

Data collected was subjected to analysis of variance (ANOVA) using the General Linear Model (GLM) of the Statistical Analysis System with mathematical model $\mathrm{Y}_{\mathrm{ij}}=\mu$ $+t_{i}+B_{j}+\varepsilon_{i j}$. Software [59] version 9.0. Mean separation was done using Fisher's LSD Test at 5\% probability level. Correlation analysis was done using Pearson's simple correlation coefficients for the intended parameters.

\section{Results and Discussion}

\subsection{Crop Phenology and Growth Parameters}

\subsubsection{Days to 50\% Heading}

The results revealed highly significant $(\mathrm{P}<0.01)$ differences among the varieties and seeding rates on the number of days needed to reach $50 \%$ heading. However, the interaction effect of seeding rate and variety did not show significant effect on days to $50 \%$ heading.

The number of days required to $50 \%$ heading varied from 56.8-75.0 among barley varieties (Table 1). Holker variety reached days to $50 \%$ heading late (75.0 days) while variety Singitan was earlier (56.8 days) as compared to the other varieties. The variation in days to $50 \%$ heading among the varieties could be attributed to the genetic differences. The difference on days to heading when grown even in similar environmental conditions was recorded among the varieties [66]. Similarly, [1] also reported significant difference among the test malt barely varieties on days to heading.

Days to $50 \%$ heading decreased by $6 \%$ when the seeding rates increased from $100-175 \mathrm{~kg} \mathrm{ha}^{1}$ (Table 1). Earliness to heading in highest seeding rate might be due to a competition to resources such as water, nutrients and sunlight, which in turn forced crop plants to escape terminal moisture stress. The results obtained by [26] also indicated that increasing sowing density from 200-400 seed per meter square in wheat crop significantly decreased the number of days to $50 \%$ heading. Similarly, [68] concluded that, increasing the levels of seeding rate decreased the days to heading consistently.

\subsubsection{Days to 90\% Physiological Maturity}

The analysis of variance indicated that the main effect of variety and seeding rates had highly significant $(\mathrm{P}<0.01)$ effects on days to $90 \%$ physiological maturity. Whereas, the interaction effect of variety and seeding rate did not shown 
marked effect on days to $90 \%$ physiological maturity.

The longest days to $90 \%$ physiological maturity was recorded from the Holker (132.42 days) variety followed by HB-1964 and Bahati (Table 2). However, the shortest days of $90 \%$ physiological maturity was recorded from IBON174/03 (123.33) and Singtan (122.50) (Table 1). The observed difference in days to physiological maturity among the five barely varieties might be attributed to inherent genotypic difference. Hence, variability among the varieties revealed that the possibility of selecting genotypes that mature earlier and adapt well in moisture deficit environments.

In line with this result [46] reported that, differences in maturity can be caused by the genetic makeup of the varieties or by the environmental conditions existing during their growth and grain filling period of the crop.

Seeding rates revealed a significant $(\mathrm{P}<0.01)$ effect on days to $90 \%$ physiological maturity (Table 1). Increasing seeding rates from $100-175 \mathrm{~kg} \mathrm{ha}^{-1}$ decreased days to $90 \%$ physiological maturity by 5 days. The highest seeding rate associated with early maturity might be due to plant competition for available resources. Higher seeding rates accelerated phenological traits, such as days to flag leaf extension, heading, mid grain filling and maturity on barely crop also reported by [19]. This result was also in line with the findings of [44] who reported earlier maturity of barley crop at higher seeding rates. However, the current findings contradict with the findings of [60]. Who reported that increasing seeding rates from $250-400$ grains $\mathrm{m}^{-2}$ caused a significant increase in days to physiological maturity of wheat.

\subsubsection{Plant Height (cm)}

The analysis of variance indicated that the variety and seeding rate had very highly significant $(\mathrm{P}<0.001)$ effects on plant height. Whereas, the interaction effect of variety and seeding rates did not show significant effect on plant height.

The tallest plant height was recorded from Holker $(91.79 \mathrm{~cm})$ variety. Whereas, the shortest value of plant height was recorded from Singitan $(73.14 \mathrm{~cm})$ variety (Table 1$)$. The observed differences in plant height among the varieties could be attributed to the genetic makeup of the varieties. This result is in line with, the findings of [62] who reported a marked variation among varieties in plant height due to the genetic makeup of the varieties as well as environmental factors.

Increasing seeding rate from 100-175 $\mathrm{kgha}^{-1}$ increased plant height by $16 \%$ (Table 2). This could be due to the reason that high competition between plants affected plant heights at the highest seeding rate. This result is similar with the findings of [55] who reported the effect of higher seeding rate on plant height, pointing out plant competition for light as main reason for having higher plant height from high seeding rate. Because increased competition for light result with increased inter node length, reduced stem thickness, thereby increase plant height. These results are in line with, [39] maximum plant height $(104.64 \mathrm{~cm})$ was obtained when seed was applied at100 $\mathrm{kg} \mathrm{ha}^{-1}$ and minimum plant height
$(96.19 \mathrm{~cm})$ was obtained in plots where $60 \mathrm{~kg} \mathrm{ha}^{-1}$ was applied at malt Barely. This result was, however, contradict with [67] reported that, plant height was significantly decreased as seeding rate increased in wheat crop.

Table 1. Effects of varieties and seeding rates on growth and phenology of barley grown under field conditions in 2018 cropping season.

\begin{tabular}{llll}
\hline Treatment & $\begin{array}{l}\text { Days to 50\% } \\
\text { heading }\end{array}$ & $\begin{array}{l}\text { Days to 90\% } \\
\text { maturity }\end{array}$ & $\begin{array}{l}\text { Plant height } \\
(\mathbf{c m})\end{array}$ \\
\hline Varieties & & & \\
Holker & $75.00^{\mathrm{a}}$ & $132.41^{\mathrm{a}}$ & $91.79^{\mathrm{a}}$ \\
HB-1964 & $66.67^{\mathrm{b}}$ & $129.08^{\mathrm{b}}$ & $82.66^{\mathrm{b}}$ \\
Bahati & $64.42^{\mathrm{c}}$ & $127.83^{\mathrm{b}}$ & $80.69^{\mathrm{b}}$ \\
IBON174/3 & $58.08^{\mathrm{d}}$ & $123.33^{\mathrm{c}}$ & $74.69^{\mathrm{c}}$ \\
Singitan & $56.75^{\mathrm{d}}$ & $122.50^{\mathrm{c}}$ & $73.14^{\mathrm{c}}$ \\
LSD $(\%)$ & 1.44 & 1.26 & 5.32 \\
Seeding rate $\left(\mathrm{kg} \mathrm{ha}^{-1}\right)$ & & \\
100 & $66.33^{\mathrm{a}}$ & $130.33^{\mathrm{a}}$ & $74.10^{\mathrm{c}}$ \\
125 & $64.66^{\mathrm{b}}$ & $127.00^{\mathrm{b}}$ & $77.76 \mathrm{~b}^{\mathrm{c}}$ \\
150 & $63.20^{\mathrm{c}}$ & $125.80^{\mathrm{c}}$ & $81.52^{\mathrm{b}}$ \\
175 & $62.53^{\mathrm{c}}$ & $125.00^{\mathrm{c}}$ & $89.00^{\mathrm{a}}$ \\
LSD (\%) & 1.29 & 1.13 & 4.76 \\
CV & 2.73 & 1.21 & 8.00 \\
\hline
\end{tabular}

Means followed by the same letter (s) within a column are not significantly different at $\mathrm{p}<0.05$ (LSD).

\subsection{Yield and Yield Related Parameters}

\subsubsection{Spike Length (cm)}

The statistical analysis results revealed that spike length was highly significantly $(\mathrm{P}<0.01)$ affected by the main effect of seeding rate and variety. Whereas, the interaction effect of variety and seeding rates did not show significant effect on spike length.

The longest spike length was recorded from variety Holker $(9.84 \mathrm{~cm}$.) while, the shortest value of spike length was recorded from singitan $(7.4 \mathrm{~cm})$ variety (Table 2$)$. The result clearly indicated that the existence of wider genetic variability for spike length among the varieties studied. This result agreed with the findings of [10], which revealed significant spike length among the malt barley varieties due to combined effects of genetic constituents and environmental factors. [36] also reported difference in genetic potential regarding to spike length.

The maximum spike length of $9.80 \mathrm{~cm}$ was recorded at those plots which received seeding rate of $100 \mathrm{~kg} \mathrm{ha}^{-1}$ while minimum and statistically similar spike length of 7.04 and $7.13 \mathrm{~cm}$ was obtained from those plots which received 175 and $150 \mathrm{~kg} \mathrm{ha}^{-1}$ seeding rates, respectively. As seed rate increased from 100-175 $\mathrm{kg} \mathrm{ha}{ }^{-1}$, the spike length was declined by $28 \%$. This might be due to more free space between plants at the lower seed rates and less plant competition for available resources that resulted in higher spike length. This significant difference on spike length among seeding rates was in line with the finding of [26], who also stated that increasing sowing density from 200-400 seed $\mathrm{m}^{-2}$ significantly decreased spike length.

\subsubsection{Number of Kernels Per Spike}

Kernels number per spike was highly significantly $(\mathrm{P}<0.01)$ different among the tested varieties. The highest number of 
kernels per spike was obtained from HB-1964 (30.40) variety while the lowest number of kernels per spike was obtained from Holker (24.04) variety. This variation is due to genotypic differences among varieties. This result is in line with [58] who indicated that a varying number of kernels per spike as a function of barely genotype. [61] Also reported genotypic differences in spikelet per spike which in turn resulted in higher numbers of grains per spike.

Table 2. Effects of varieties and seeding rates on yield related parameters of barley grown under field conditions in 2018 cropping season.

\begin{tabular}{lll}
\hline Treatment & Spike length $(\mathrm{cm})$ & Number of kernels spike \\
\hline Varieties & & \\
Holker & $9.84^{\mathrm{a}}$ & $24.04^{\mathrm{d}}$ \\
HB-1964 & $8.30^{\mathrm{b}}$ & $30.40^{\mathrm{a}}$ \\
Bahati & $7.73^{\mathrm{bc}}$ & $27.75^{\mathrm{b}}$ \\
IBON174/03 & $7.54^{\mathrm{c}}$ & $26.33^{\mathrm{bc}}$ \\
Singitan & $7.36^{\mathrm{c}}$ & $24.82^{\mathrm{cd}}$ \\
LSD $(\%)$ & 0.71 & 2.01 \\
Seeding rate $\left(\mathrm{kg} \mathrm{ha}^{-1}\right)$ & \\
100 & $9.80^{\mathrm{a}}$ & $30.61^{\mathrm{a}}$ \\
125 & $8.59^{\mathrm{b}}$ & $26.82^{\mathrm{b}}$ \\
150 & $7.13^{\mathrm{c}}$ & $25.38^{\mathrm{bc}}$ \\
175 & $7.04^{\mathrm{c}}$ & $23.86^{\mathrm{c}}$ \\
LSD $(\%)$ & 1.79 & 1.79 \\
CV & 10.48 & 8.03 \\
\hline
\end{tabular}

Means followed by the same letter (s) within a column are not significantly different at $\mathrm{p}<0.05$ (LSD). Number of productive tiller per $\left(\mathrm{m}^{2}\right)$.

The main effect of seeding rates revealed highly significant $(\mathrm{P}<0.01)$ effect on kernels number per spike. Maximum number of kernels per spike (30.61) was obtained from $100 \mathrm{~kg} \mathrm{ha}^{-1}$ seeding rate. However, minimum number of kernels per spike (23.86) was recorded from the seeding rate of $175 \mathrm{~kg} \mathrm{ha}^{-1}$. As seeding rate increased from $100-175 \mathrm{~kg}$ $\mathrm{ha}^{-1}$, the number of kernels per spike was decreased by $28.2 \%$ (Table 3). Since grain filling is dependent on nutrient supply and environmental condition, increasing plant density resulted in increased competition for nutrients and sun light at later stages, and finally most grains would fade at early stages, because of competition between growing grains to absorbing reserved matters and as a result low grains would be produced.

The result obtained from this study was in line with [30] who reported that the higher grain number obtained in the lowest seeding rate can be attributed to more light penetration through plant canopy. The decreased in number of grains per spike by increasing sowing rates may be due to excessive densities [6] Furthermore, increasing seeding rates from 100 to $150 \mathrm{~kg} \mathrm{ha}^{-1}$ decreased the number of grains per spike from 32.02 to 29.60 [68]. However, these findings were in line with [45] who reported that by increasing seeding rate the number of grains per spike was reduced.

\subsubsection{Number of Productive Tiller Per $\left(m^{2}\right)$}

Among the yield components, productive tillers are very important because the final yield is mainly a function of the number of spike bearing tillers per unit area. The analysis of variance indicated that the main effects of variety and seeding rate had significant $(\mathrm{P}<0.05)$ and highly significant effect $(\mathrm{P}<0.01)$ on number of productive tillers, respectively. Likewise, the interaction effect of variety and seed rates also revealed highly significant $(\mathrm{P}<0.01)$ differences on the productive tillers per $\mathrm{m}^{2}$.

The highest number of productive tillers (1017.33 per $\mathrm{m}^{2}$ ) was obtained at the combination of variety Singitan with 150 $\mathrm{kg} \mathrm{ha}^{-1}$ seed rates while; the lowest number of productive tillers $\left(358.67\right.$ per $\left.\mathrm{m}^{2}\right)$ was obtained at combination of variety HB-1964 with $100 \mathrm{~kg} \mathrm{ha}^{-1}$ seed rate (Figure 1). Such increment in number of productive and spikes due to increasing sowing density could be attributed to increasing number of plants per $\mathrm{m}^{2}$. On the other hand, the lower number of productive tillers for variety HB-1964 might be attributed to the death of the secondary and tertiary tillers due to the occurrence of low precipitation late in the growing period and variety HB-1964 was very susceptible to barely yellow dwarf virus than other varieties during cropping season on experimental site. This result in agreement with, [7] who indicated that secondary tillers die without producing spikes which is deleterious to grain production, as they waste assimilate, water, and nutrients that would otherwise have contributed to grain yield. Similarly, [2] reported that the number of effective tillers increased as seeding rate increased. There was linear increase in number of fertile tillers with increased seeding rate and among seeding rates, $200 \mathrm{~kg} \mathrm{ha}^{-1}$ produced significantly higher number of productive tillers (278.75) followed by $175 \mathrm{~kg} \mathrm{ha}^{-1}$ seeding rate (263.97) on wheat crop [32].

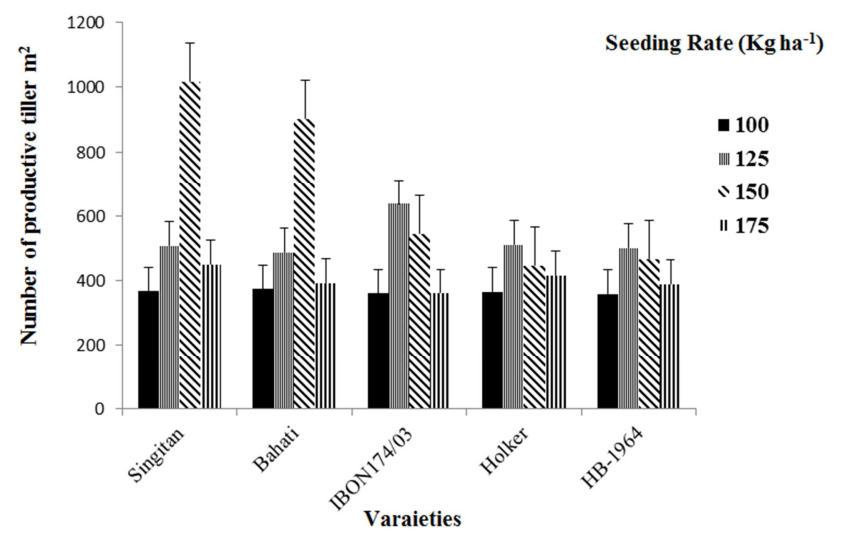

Figure 1. Interaction effect of variety and seeding rate on number of productive tiller of malt barely. Vertical lines on bars represent standard error of the statistical means.

\subsubsection{Thousand Kernels Weight}

The analysis of variance indicated that both variety and seeding rate had highly significant $(\mathrm{P}<0.01)$ effect on thousand kernels weight. Whereas, their interaction effect was not significant on thousand kernels weight.

Among the tested varieties the heaver thousand kernel weight was produced from the variety Singitan (43.52gm) followed by variety Bahati (43.30gm). While, the lowest thousand kernels weight was produced by Holker (36.44gm) variety (Table 3). The superior kernel weight of Singitan and Bahati over other varieties might be attributed due to genetic makeup of these varieties which might lead to an increased 
photosynthesis and accumulations of carbohydrate in kernel to produce heavy kernels and consequently increased kernels weight per spike. Similarly, the studies conducted by [50] indicated that a very high heritability value for 1000 kernel weight of $99.9 \%$. [28] also indicated greater genetic effect on grain size over environmental effect even when experimental sites suffered terminal moisture stress.

The highest thousand kernels weight (43.96 g) was recorded for seeds sown at the seeding rate of $100 \mathrm{~kg} \mathrm{ha}^{-1}$ whereas the lowest thousand kernel weight (35.59 g) was recorded at the seeding rate of $175 \mathrm{~kg} \mathrm{ha}^{-1}$ (Table 3). Generally when seeding rate increased from $100-175 \mathrm{~kg} \mathrm{ha}^{-1}$ resulted in decreased thousand kernels weight by $23.51 \%$. This could be due to high density caused to increasing number of spikes, and as a result of competition would increase and little photosynthesis would be available to grain filling and finally thousand grain weight would reduce due to increasing number of spikes. Therefore, insufficient photosynthesis during grain filling stage in thick density may be the possible reason to decrease thousand kernel weights. This result is in line with [54] who indicated that the kernel weight, diameter and seed plumpness were lower at higher seeding rates. Similarly, [24] also found that heavier kernels weights by using low seeding rates. [54] also indicated the largest decreases in kernel plumpness tended to occur at seeding rates above 300 seeds $\mathrm{m}^{2}$ with a relatively minor decline as seeding rate increased from 100-300 seeds $\mathrm{m}^{2}$. Similarly, [32] concluded that lower seeding rates (125 kg ha$\left.{ }^{1}\right)$ produced significantly heavier grains (40.74 g) than higher seeding rate $\left(200 \mathrm{~kg} \mathrm{ha}^{-1}\right)$ that produced lighter $(37.83 \mathrm{~g})$ grains.

\subsubsection{Grain Yield}

The result concerning grain yield showed that there were highly significant $(\mathrm{P}<0.01)$ differences in grain yield among malt barely varieties and seeding rates. Interaction among varieties and seed rates was also significant $(\mathrm{P}<0.05)$.

The maximum grain yield was produced from Singitan (3.63 $\left.\mathrm{t} \mathrm{ha}^{-1}\right)$ and Bahati $\left(3.11 \mathrm{t} \mathrm{ha}^{-1}\right)$ varieties combined with seeding rate of $150 \mathrm{~kg} \mathrm{ha}^{-1}$, respectively. While, the lowest grain yield was produced from HB-1964 $\left(1.00 \mathrm{t} \mathrm{ha}^{-1}\right)$ variety combined with $100 \mathrm{~kg} \mathrm{ha}^{-1}$ seeding rate (Figure 2). The results further revealed marked differences among the varieties and seeding rates. For instance, varieties Singitan, Bahati and HB-1964 required $150 \mathrm{~kg} \mathrm{ha}^{-1}$ seeding rate for maximum grain yield production, whereas, the varieties IBON174/03 and Holker required $125 \mathrm{~kg} \mathrm{ha}^{-1}$ seeding rate for producing higher grain yield. The highest grain yield from the varieties Singitan and Bahati might be attributed due to the production of higher thousand-kernel weight than the reset varieties. Furthermore, the highest number of productive tillers per $\mathrm{m}^{-2}$ was obtained from these varieties with combination of $150 \mathrm{~kg} \mathrm{ha}^{-1}$ seeding rates. Hence, productive tillers are very important because the final yield is mainly a function of the number of spike bearing tillers per unit area.

This result is in line with [28] who reported that the yield and quality specifications of a given malting barley variety are determined by its genetic makeup and the physical conditions during growth and harvesting time. Similarly, $[34,64]$ indicated that productive tillers per plant, number of kernels per spike and thousand kernel weight would be more useful criteria for selecting evolving high yielding varieties.

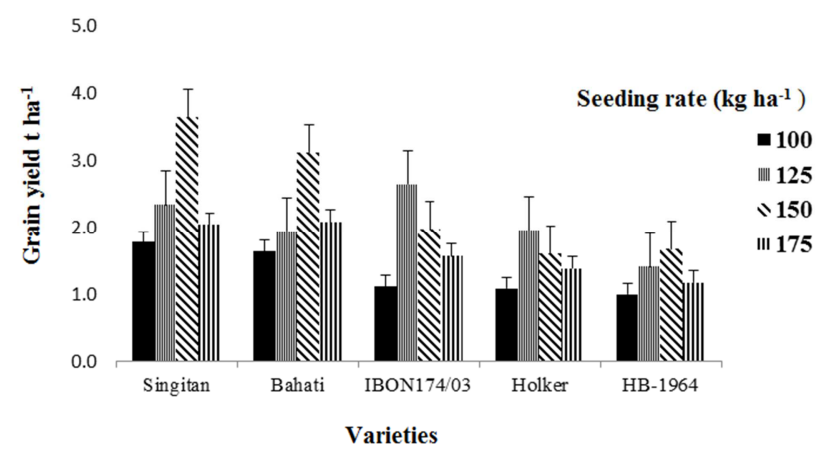

Figure 2. Interaction effect of variety and seeding rate on grain yield of malt barely. Vertical lines on bars represent standard error of the statistical means.

\subsubsection{Above Ground dry Biomass Yield ( $\left.\mathrm{ha}^{-1}\right)$}

Analysis of variance showed that the main effect of seeding rate and variety had highly significant $(\mathrm{P}<0.01)$ effect on the above ground dry biomass yield. However, the interaction effect of seeding rate and variety was not significant.

The highest above ground dry biomass yields was obtained from Holker $\left(12.38 \mathrm{t} \mathrm{ha}^{-1}\right)$ variety, while the lowest value of above ground dry biomass yield was obtained from IBON174/03 (9.22 $\mathrm{t} \mathrm{ha}^{-1}$ ) variety (Table 3). The greater above ground dry biomass of Holker variety might be attributed due to the tallest plant height than other varieties. This result in line with [70] who reported that the positive association between biomass yield and plant height, in which the taller plants resulted higher biomass yield.

Highest above ground dry biomass yield (12.37 $\left.\mathrm{t} \mathrm{ha}^{-1}\right)$ was observed at the seeding rate of $175 \mathrm{~kg} \mathrm{ha}^{-1}$ while lowest above ground dry biomass yield $\left(9.78 \mathrm{t} \mathrm{ha}^{-1}\right)$ was observed at the seeding rate of $100 \mathrm{~kg} \mathrm{ha}^{-1}$ (Table 3). The higher above ground dry biomass yield with increased seed rate might be due to an increase in plant population and tallest plant height as seed rate increased. The current result is in line with the finding of [33] who indicated that higher biomass yield was recorded on increased seeding rates of 200-175 $\mathrm{kg} \mathrm{ha}^{-1}$. [60] Confirmed that increasing seeding rates up to $350-400$ grains $\mathrm{m}^{-2}$ increased grain, straw and biomass. Moreover, [26] reported that the highest value of biological yield was obtained with increasing seed rate up to 400 grains $\mathrm{m}^{2}$. 
Table 3. Effects of varieties and seeding rates on yield components, grain quality and yellow dwarf virus of barley grown under field conditions in 2018 cropping season

\begin{tabular}{|c|c|c|c|c|}
\hline Treatment & Thousand kernels weight (g) & Above ground biomass yield $\left(\mathrm{t} \mathrm{ha}^{-1}\right)$ & Hectoliter weight $\left(\mathrm{kg} \mathrm{hl}^{-1}\right)$ & Barely yellow dwarf virus \\
\hline \multicolumn{5}{|l|}{ Varieties } \\
\hline Holker & $36.44^{\mathrm{d}}$ & $12.38^{\mathrm{a}}$ & $61.53^{\mathrm{bc}}$ & $2.16^{\mathrm{c}}$ \\
\hline HB-1964 & $39.27^{\mathrm{c}}$ & $9.61^{\mathrm{b}}$ & $54.96^{\mathrm{d}}$ & $5.67^{\mathrm{a}}$ \\
\hline Bahati & $43.30^{\mathrm{a}}$ & $12.04^{\mathrm{a}}$ & $63.55^{\mathrm{a}}$ & $4.08^{\mathrm{b}}$ \\
\hline IBON174/03 & $41.77^{\mathrm{b}}$ & $9.22^{\mathrm{b}}$ & $60.83^{\mathrm{c}}$ & $2.5^{\mathrm{c}}$ \\
\hline Singitan & $43.52^{\mathrm{a}}$ & $11.44^{\mathrm{a}}$ & $62.98^{\mathrm{ab}}$ & $2.67^{\mathrm{c}}$ \\
\hline $\operatorname{LSD}(\%)$ & 1.33 & 1.24 & 1.52 & 0.71 \\
\hline \multicolumn{5}{|c|}{ Seeding rate $\left(\mathrm{kg} \mathrm{ha}^{-1}\right)$} \\
\hline 100 & $43.96^{\mathrm{a}}$ & $9.77^{\mathrm{c}}$ & $64.4^{\mathrm{a}}$ & $3.47^{\mathrm{a}}$ \\
\hline 125 & $42.63^{\mathrm{b}}$ & $10.27^{\mathrm{bc}}$ & $61.29^{\mathrm{b}}$ & $3.50^{\mathrm{a}}$ \\
\hline 150 & $41.25^{\mathrm{c}}$ & $11.32^{\mathrm{ab}}$ & $60.1^{\mathrm{b}}$ & $3.46^{\mathrm{a}}$ \\
\hline 175 & $35.59^{\mathrm{d}}$ & $12.37^{\mathrm{a}}$ & $57.24^{\mathrm{c}}$ & $3.20^{\mathrm{a}}$ \\
\hline LSD (\%) & 1.18 & 1.11 & 1.36 & 0.63 \\
\hline $\mathrm{CV}$ & 3.75 & 10.48 & 3.03 & 22 \\
\hline
\end{tabular}

Means followed by the same letter (s) within a column are not significantly different at $\mathrm{p}<0.05$ (LSD).

\subsubsection{Harvest Index}

The physiological ability of a crop plant to convert proportion of dry matter into economic yield is measured in terms of harvest index. The result indicated that the main and interaction effect of variety and seeding rate had highly significant $(\mathrm{P}<0.01)$ effect on the harvest index.

The highest harvest index $(32.75 \%)$ and $(31.16 \%)$ values were obtained from the variety Singitan and IBON174/03 with the combination of $150 \mathrm{~kg} \mathrm{ha}^{-1}$ and $125 \mathrm{~kg} \mathrm{ha}^{-1}$ seeding rate, respectively. While the lowest harvest index $(9.43 \%)$ was recorded from variety HB-1964 with the combination of $175 \mathrm{~kg} \mathrm{ha}^{-1}$ seeding rate (Figure 3). In line with this finding, [20] reported that grain yield is proportional to harvest index and factors which make up grain yields such as grain weight and grains per spikelet have a relatively high effect on harvest index. The harvest index value showed decrement with increasing seeding rates which clearly indicates that the translocation of photosynthetic towards the sink was affected adversely, and they were accumulated in other parts [35].

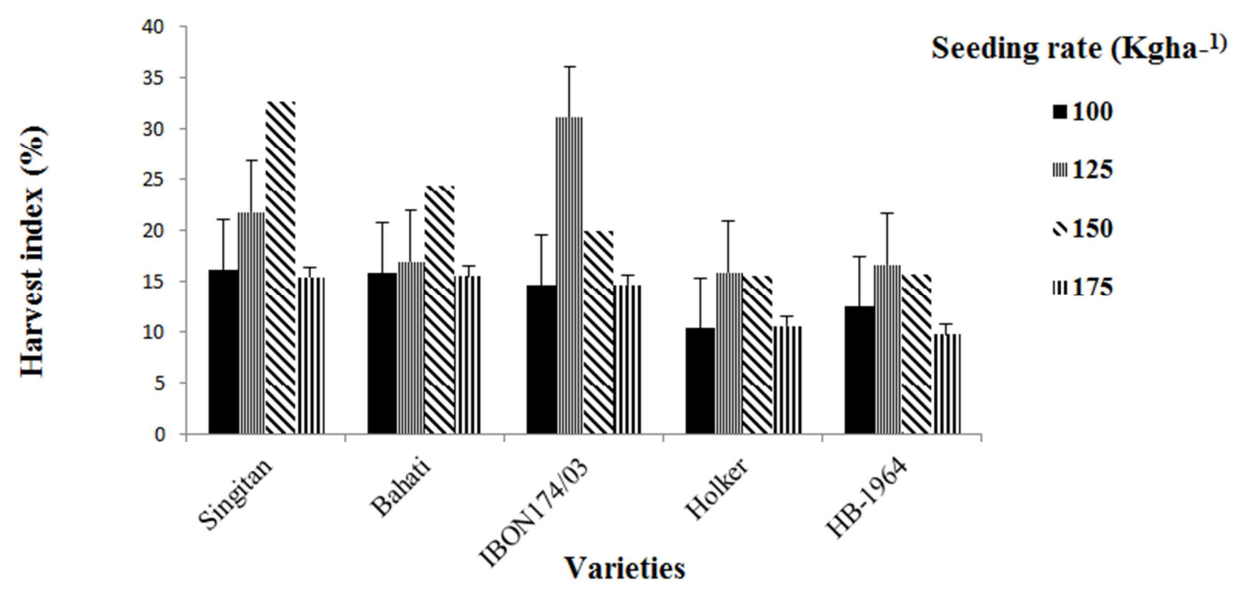

Figure 3. Interaction effects of variety and seeding rate harvest index on malt barely. Vertical lines on bars represent standard error of the statistical means.

\subsection{Quality Parameters}

\subsubsection{Hectoliter Weight}

The result showed that the main effect of variety and seeding rate had highly significant $(\mathrm{P}<0.01)$ effect on the hectoliter weight. However, their interaction effects were not significant.

The highest hectoliter weight was recorded from the Singitan $\left(62.98 \mathrm{~kg} \mathrm{hl}^{-1}\right)$ variety whereas; the lowest hectoliter weight was recorded from HB-1964 (54.96 kg hl-1) variety (Table 3). The result obtained in variety HB-1964 was lower as compared with other variety because of this variety is affected by barely yellow dwarf virus at experimental site and it have poor grain filling and shrived grain. This result is in line with [11] who reported that low values of hectoliter weight indicate poor grain filling and climatic influences leading to grain shriveling which can impair specific weight through reduced packing efficiency.

Hectoliter weight was decreased as seed rate increased from $100-175 \mathrm{~kg} \mathrm{hl}^{-1}$ by $12 \%$ (Table 3 ). Similar result was obtained by [9] who reported that increasing seeding rate from 350-800 seeds per $\mathrm{m}^{2}$ significantly decreased hectoliter weight. According to the Ethiopian quality standard, the acceptable grain size (thousand-kernel weight) and test weight (hectoliter weight) for raw barley are in the range 25$35 \mathrm{~g}$ and $48-62 \mathrm{~kg} \mathrm{hl}^{-1}$, respectively [47]. The standards set 
for thousand kernel weight and hectoliter weight by National Standard Authority ranged from $35-45 \mathrm{~g}$ and $60-65 \mathrm{~kg} \mathrm{hl}^{-1}$, respectively [49]. Therefore, the results of the present experiment exhibited an acceptable thousand kernel and hectoliter weight in all varieties except HB-1964 variety and with the combination of $100-150 \mathrm{~kg} \mathrm{ha}^{-1}$ seed rate.

\subsubsection{Grain protein Content}

Grain protein content exceed from the recommended levels were undesirable for malt factory that increase the steeping time and cause uneven water uptake during steeping, create uneven germination during malting, and increase malt loss due to abnormal growth [42]. On the other hand, lower protein content is usually correlated with low carbohydrate levels and lower extract values [38]. This causes adverse effects in fermentation, due to the poor amino acid content available for yeast nutrition.

The result showed that there were highly significant $(\mathrm{P}<0.01)$ differences in grain protein content among malt barley varieties and seed rates. Interaction among varieties and seed rates was also significant $(\mathrm{P}<0.05)$.

The highest grain protein content $(13.5 \%)$ was recorded

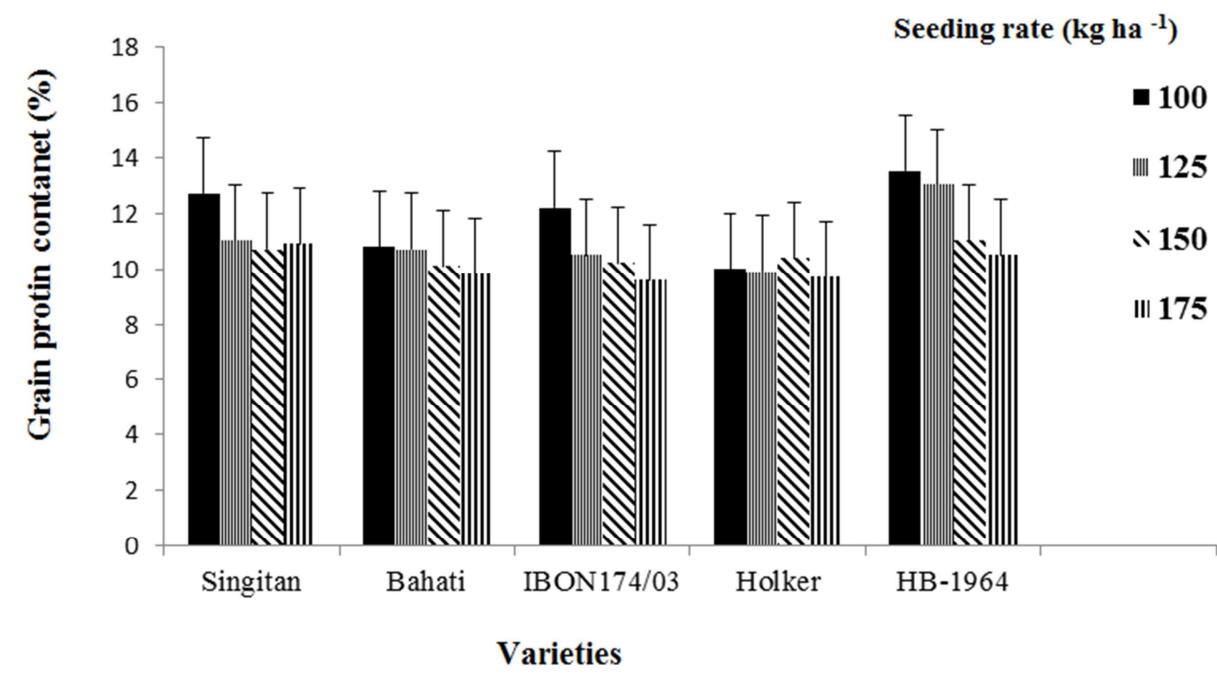

Figure 4. Interaction effect of variety and seeding rate on grain protein content on malt barely. Vertical lines on bars represent standard error of the statistical means.

\subsection{Barley Yellow Dwarf Viruses}

Barley yellow dwarf virus is caused by viruses, economically damaging and the most widespread disease of cereals in worldwide [13]. Symptoms of the disease bright yellowing or reddening of the leaves starting from the tip and developing towards the base, stunting the crop, white sterile spikes and the presence of aphids are commonly observed [65]. Analysis of variance showed that the effect of seeding rate and the interaction effect of variety and seeding rate were not significant on barley yellow dwarf viruses. However, the effect of variety was highly significant $(\mathrm{P}<0.01)$ effect on it.

Among the varieties the highest barley yellow dwarf virus score was obtained from HB-1964 (5.67\%) variety followed by Bahati $(4.08 \%)$ variety. However, the lowest barley from the variety HB-1964 when combined with seeding rate of $100 \mathrm{~kg} \mathrm{ha}^{-1}$ while, the lowest $(9.6 \%)$ grain protein content was recorded from the variety IBON174/03 and seeding rate of $175 \mathrm{~kg} \mathrm{ha}^{-1}$ (Figure 4). This could be due to protein accumulations of varieties are affected by genetic makeup during grain filling period. This result is in line with [56] who reported that protein accumulates during grain filling period of malt barley depends on the variety in which constituting the genetic makeup and growing environmental condition. Regarding to seeding rate grain protein content decreased with higher seeding rate in all varieties. This result is in line with, [12] report which indicates that protein concentration decreased as seeding rate increased. Similarly, [43] also indicated that higher seeding rates reduced grain protein concentrations, with an average decline of $4 \mathrm{mg} \mathrm{g}^{-1}$ from the highest seeding rates to the lowest seeding rate. According to [21] the national standard value of kernel protein content $9-11.5 \%$. Therefore, the varieties which have the highest grain yield and low grain protein content fulfill the requirements of malt factories. 

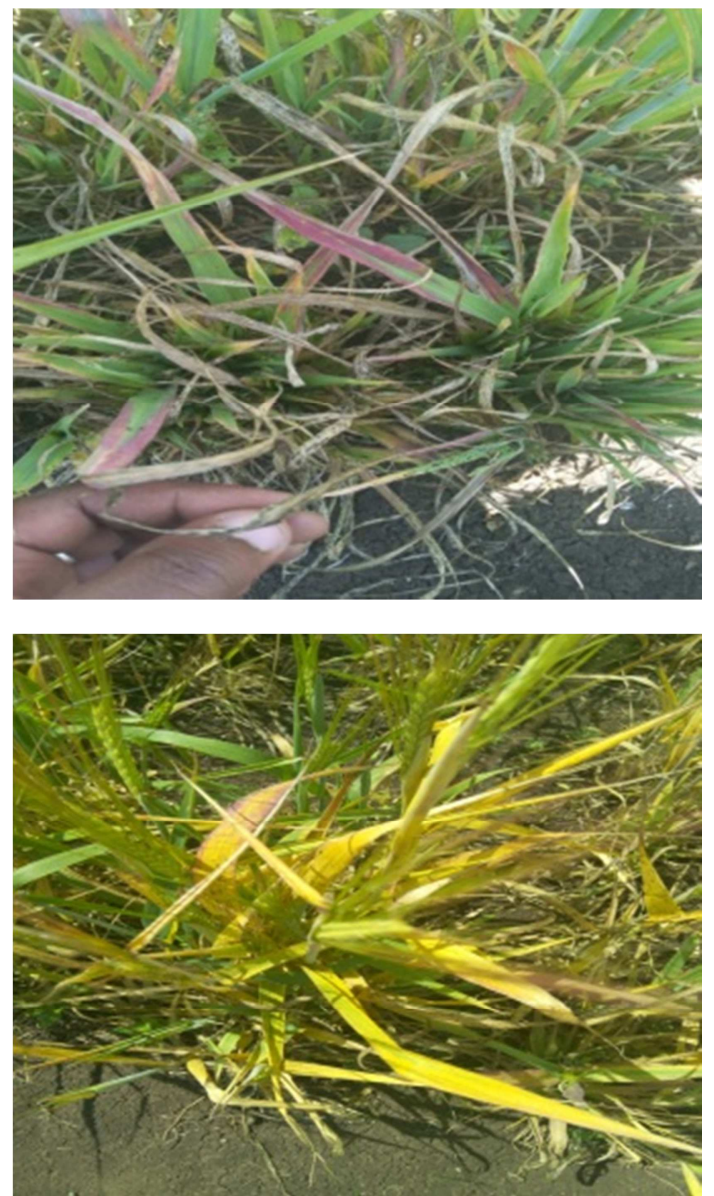

Figure 5. Malt barely (HB-1964) infected by barely yellow dwarf virus in the experimental site.

\section{Conclusion}

In general, significant differences for most of agronomic parameters, grain yield and protein quality of malt barely were observed due to variety and seeding rates. From the result of this study, the use of variety Singitan, Bahati and HB-1964 required $150 \mathrm{~kg} \mathrm{ha}^{-1}$ seed rate and variety IBON174/03 and Holker required $125 \mathrm{~kg} \mathrm{ha}^{-1}$ seed rate for producing higher grain yield and protein quality. This is due to the highest number of productive tillers produced by the varieties per $\mathrm{m}^{2}$ basis, and further, the economic yield of most of the cereals is determined by the number productive tillers.

\section{References}

[1] Akalu Gebru. 2018. Evaluation of grain yield performance and quality parameter of malt barley (Hordeum vulgare L.) variety in Eastern Amhara Region, Ethiopia. Journal of Agricultural Sciences, 2333-6668.

[2] Ali M. 2010. Improvement in wheat (Triticum aestivum L.) Yield by manipulating seed rate and row spacing in vehari zone. Adaptive Research Farm, Vehari. Journal of Animal and Plant sciences, 20 4): 225-230.

[3] Amare Aleminew and Adane Legas. 2015. Grain quality and yield response of malt barley varieties to nitrogen fertilizer on brown soils of Amhara region Ethiopia. Journal of Agricultural Sciences, 11 (3): 135-143.

[4] Anonymous. 2012. Progress report of all India coordinated wheat and barley improvement project 2011-12. Barley Network. Directorate of Wheat Research, Karnal, India.

[5] AMF (Assela Malt Factory). 2012. Current annual beer production capacity and malt requirement of Ethiopian breweries 2012/2013. Assela, Ethippia.

[6] Assefa W., Yemane N., Dawit H. 2015. Planting density and nitrogen and phosphorus fertilization effect on different bread wheat (Triticum aestivum L.) genotypes in Southern Tigray, Ethiopia. World Journal of Science and Research, 3 (2): 20-28.

[7] Asfaw Z. 2000. The Barleys of Ethiopia. Stephen B. Brush (ed). Genes in the Field: On farm Conservation of Crop Diversity, IPGRI/IDRC, Pp. 77-109.

[8] Arabi M. I., Jawhar M., Al-Safadi B., MirAli N. 2004. Yield responses of barley to leaf stripe (Pyrenophora graminea) under experimental conditions in southern Syria. Journal of Phytopathology, 152: 519-523.

[9] Bavec M., Bavec F., Varga B. and Kovacevic V. 2002. Relationships among yield, it's quality and yield components in winter wheat (triticum aestivum L.) cultivars affected by seeding rates. Slovenia Journal of Agriculture, 53 (3): 143151.

[10] Biruk Gezahegn and Demelash Kefale. 2016. Effect of Nitrogen Fertilizer Level on Grain Yield and Quality of Malt Barley (Hordeum vulgare L.) Varieties in Malga Woreda, 52, $8-16$.

[11] Bleidere M. 2008. Genetic and environmental effect on the grain quality of spring barley. Latvian Journal of Agronomy, 11: 33-39.

[12] Brewing and Malting Barley Research Institute. 2010. Quality factors in malting barley. A Brewing and Malting Barley Research Institute Publication. 1510.

[13] Burnett P. A. 1984. Preface. in: P. A. Burnett (ed). World Perspectives on Barley Yellow Dwarf. Proceedings of $a$ Workshop. CIMMYT, Mexico.

[14] Campbell C. and Madden. L. 1990. Introduction to Plant Disease Epidemiology. John Wileey and Sons New York.

[15] Costa J. M. and Bodlero G. 2001. Annals applied biology. 139 (1): $137-143$.

[16] CSA (Central Statistical Agency). 2016. Agricultural sample survey: area and production of major crops, meher season. Addis Ababa, Ethiopia.

[17] Dagnachew Yirgu. 1967. Index of Plant Diseases in Ethiopia. College of Agriculture Haile Sellassie Imperial University Experimental Station Bulletin, No. 30: 1-67.

[18] David E., Kevin R. and Anthony K. 2014. The influence of malt quality on malt brewing and barley quality on barley brewing with ondea pro, compared by small-scale analysis Journal of the American Society of Brewing Chemists, 72 (3): 192-207.

[19] Doffing S. M. and Knight. 1992. Heading synchrony and yield components of barley Grown in Subarctic environments. Crop Science, 32: 1377-1380. 
[20] Donald C. M. and Hamblin J. 1976. The biological yield and harvesting index of cereal as agronomic and plant breading criteria. Advance in Agronomy, 28: 156-163.

[21] ERCA (Ethiopian Revenues and Customs Authority). 2014.

[22] Ethiopia-Barley-Business-Case Investor Presentation. 2012. The Business Case for Investing in Malting Plant in Ethiopia, Investor Presentation. Addis Ababa, Ethiopia.

[23] FAO (Food and Agriculture Organization). 2014. Food Balance Sheets. FAOSTAT Rome.

[24] Froment. 2003. Barley quality and grain size homogeneity for malting. Agronomic effects on varieties. Project Rep. No. 320. Home Grown Cereals Authority, Stoneleigh Park, Kenilworth, Warwickshire, UK.

[25] Fox G. P., Panozzo J. F., Li C. D., Lance R. C. M., Inkerman P. A. and Henry R. J. 2006. Molecular basis of barley quality. Australian Journal of Agricultural Research, 54: 1081-1101.

[26] Gafaar N. A. 2007. Response of some bread wheat varieties grown under different levels of Planting density and nitrogen fertilizer. Minufiya Journal of Agriculture, 32: 165-183.

[27] Geleta B., Atak M., Baenziger P. S., Nelson L. A., Baltenesperger D. D., Eskridge K. M., Shipman M. J. and Shelton D. R. 2002. Seeding rate and genotype effect on agronomic performance and end-use quality of winter wheat. Journal of Crop Science, 42: 827-832.

[28] Glen P. F., Kelly A., Poulson D., Inkerm A. and Henry R. 2006. Selecting for increased barley grain size Journal of cereal science, 43 (2): 198-208.

[29] Hamid E., Taj F. H., Bakht J., Shah A. W. and Shad A. 2002. Effect of different planting dates, seed rates and nitrogen levels on wheat. Asian Journal of Plant Science, 1: 502-506 Hazelton, P. and Murphy B. 2007. Interpreting Soil Test Results, CSIRO Publishing, 150 Oxford Street Collingwood VIC 3066, Australia.

[30] Hussanein M. S. 2001. Effect of variety and nitrogen levels on growth, yield and yield components of wheat in Newly Cultivated land. Egyptian. Journal of Agronomy, 23: 111-131.

[31] IGC (International Grains Council). 2013. five-year global supply and demand projections. 10 December 2013.

[32] Iqbal, Akbar and Ali. 2010. Effect of seed rate and row spacing on yield and yield components of wheat (Triticum aestivum L.). Adaptive Research Farm, Vehari, Pakistan. Journal of Agricultural Research, 48 (2): 151-156.

[33] Jemal Abdulkerim, Tamado Tana and Firdissa Eticha. 2015. Response of bread wheat (Triticum aestivum L.) varieties to seeding rates at Kulumsa, south eastern Ethiopia. Asian Journal of Plant Sciences, 14 (2): 50-58.

[34] Kavitha G., Dhindsa G. S., Singh S. and Singh J. 2009. Stability analysis of yield and its components in malt barley (Hordeum vulgare L.) genotypes. Journal of Crop Improvement, 36 (1): 29-34.

[35] Kazimierz N. 2010. Effect of sowing rate on yields and grain quality of new cultivars of spring Department of Cereal Crop Production Institute of Soil Science and Plant CultivationNational Research Institute in Puławyul. Czartoryskich 8, 24100 Puławy, Poland Barley. Polish Journal of Agronomy, 3.

[36] Khan M. A., Anwar A. and khtar M. 2001. Effect of seed rate on wheat yield under different sowing dates and row spacing. Journal Agricultural Research, 39 (3-4): 223-229.

[37] Kifle Zerga, Firew Mekbib, Tadesse Dessalegn. 2016. Estimation of association among growth and yield related traits in Bread Wheat (Triticum aestivum L.) Genotypes at Gurage Zone, Ethiopia. Journal Plant Breed Crop Science, 3: 123-134.

[38] Krstanović V., Lalić A., Kosović I., Velić, N., Mastanjević, K., Mastanjević, K. 2016. A survey of total $\beta$-glucan content in Croatian barley varieties. Cereal Research, 44 (4): 650-657.

[39] Lake Mekonnen. 2018. Effects of seed and $\mathrm{n}$ rate on grain yield and yield components of barley southern Agricultural Research Institute, Worabe Agricultural Research Center, Department of crop Science. Journal of Natural Sciences Research, 3 (85): 603-614.

[40] Leisrumaite A. and Paplauskiene V. 2005. Genetic resources of malt barley: Screening for yield stability and grain malt quality traits.

[41] Liu Z., Simon R., Ellwood, Richard P., Oliver and Timothy L. Friesen. 2011. Pyrenophora teres: profile of an increasingly damaging barley pathogen. Molecular Plant Pathology, 12 (1): $1-19$.

[42] Mastanjević, Kristina, Lenart L., Gordana Šimić, Lalić A. 2018. Malting quality indicators of Croatian dual-purpose barley varieties. Journal of Food Science Technology, 9 (2) 145-151.

[43] McKenzie R. H., Middleton A. B. and Bremer E. 2005. Fertilization, seeding date, and seeding rate for malting barley yield and quality. Southern Alberta Canadian Journal Plant Science, 85: 603-614.

[44] McKenzie R. H., Bremer E., Middleton A. B., Pfiffner P. G. and Woods S. A. 2011. Optimum seeding date and rate for irrigated cereal and oilseed crops. Southern Alberta Canadian Journal Plant Science, 91: 293-303.

[45] Mehrvar M. R. and Asadi H. 2006. Agronomical and economical assessment of planting methods and seeding rates in irrigated wheat. Journal of Agronomy, 5 (4): 626-633.

[46] Melle Tilahun and Tesfaye Jorgi. 2014. Phenotype performance and grain yield stability of malting barley Genotype across North western Ethiopia. Proceeding of 6th and $7^{\text {th }}$ annual and regional on completed crop research activity (ARARI) February 2014, Amhara Region Agricultural Research Institute. 96-100.

[47] Minale Liben, Alemayehu Assefa and Tilahun Tadesse. 2011. Grain yield and malting quality of barley in relation to nitrogen application at mid and high altitude in Northwest Ethiopia. Journal of Science and Development, 1 (1): 75-88.

[48] Molinacane J. L., Fra Mon P., Salcedo G., Aragoncillo C., and Garcia-Olmedo F. 2001. Morocco as a Possible Domestication Centre for Barley: Biochemical and Agro morphological Evidence of Applied Genetics, 73: 531-536.

[49] Muluken Bantayehu. 2013. Study on malting barley genotypes under diverse agro ecologies of north western Ethiopia. Adet Agricultural Research Center. Bahirdar, Ethiopia.

[50] Nanak C., Vishwakarma O. P., Verma and Kumar M. 2008. Worth of Genetic Parameters to Sort-out New Elite Barley Lines over Heterogeneous Environments. Barley genetics newsletter, 38: 10-13. 
[51] National Barley Research Program (NBRP). 2016. The Barley Commodity Research Strategy of Fifteen Years (2016-2030).

[52] Nefo Kadir, Geleto Tilahun and Aman Alo. 2008. Fifteen years achievements: Oromia Agricultural Research Institute, sinana Agricultural Research centre, bale- Robe, southeast Ethiopia.

[53] O’Donovan J. T., Clayton G. W., Grant C. A., Harker K. N., Turkington T. K., and Lupwayi N. Z. 2008. Eff ect of nitrogen rate and placement and seeding rate on barley productivity and wild oat fecundity in a zero tillage system. Crop Science, 48: 1569-1574.

[54] O'Donovan J., Turkingtonb T., Edneyc M., Claytond G., McKenziee R., Patriciaf P. E., Lafondg G. P., Granth C. A., Brandti S., Harkerj K. N., Johnsonk E. N and May W. E., 2011. Seed rate, nitrogen rate, and cultivar effects on malting barley. Crop Agricultural Journal, 103 (3): 709-716.

[55] Otteson B. N., Mergoum M. and Ransom J. K. 2007. Seeding rate and nitrogen management Effect on spring wheat yield and yield components. Agronomy Journal, 99: 1615.

[56] Pettersson C. G, Franknow Lindburg B. E. 2006. Reappraisal of methods of application of nutrient at sowing on yield, grain and protein content economy of malt barley.

[57] Roland. 2011. Important raw materials quality parameters and their influence on beer production. Brewing Conference, Bangkok.

[58] Ryan J., Abdel Monem and Amri A. 2009. Nitrogen fertilizer response of some barley Varieties in semi-arid conditions. Morocco Journal of Agricultural Science and Technology, 11: 227-236.

[59] SAS (statistical analysis system). 2002. SAS for windows, release 9.0. SAS Institute, Inc., Cary, NC, USA.

[60] Seleiman M. F., Ibrahim M. E., Abdel-Aal and Zahran G. A. 2010. Effect of seeding rates on productivity, technological and rheological characteristics of bread wheat (Triticum aestivum L.). International Journal of Current Research, 4: 075-080.
[61] Schulthess U. 1992. The impact of Verti soil management systems on wheat production in the Ethiopian high lands. Ph. D. Thesis, Federal Institute of Technology, Zurich.

[62] Shahzad M A., Khan M. M, Ehsanullah and Ahmad M. 2007. Effect of sowing dates and seed treatment on grain yield and quality of wheat. Pakistan Journal of Agricultural Science, 44 (4): 581-583.

[63] Singh N. P. and Singh R. A. 2002. Scientific crop production, press Graphics, Delhi-28, $1^{\text {st }}$ (e. d) India.

[64] Sukram P., Tejveer S. and Ramesh B. 2010. Estimation of Genetic Parameters in Barley (Hordeumvulgare L.); Journal of Crop Improvement (Abs.) 37 (1): 52-56.

[65] Stewart R. B. and Dagnachew Yirgu. 1987. Index of Plant Diseases in Ethiopia. College of Agriculture Haile Sellassie Imperial University Experimental Station Bulletin, No. 30: 167.

[66] Soomro U. A., Ur Rahman M., Odhano E. A., Gul S., Tareen A. Q. 2009. Effects of Sowing Method and Seed Rate on Growth and Yield of Wheat (Triticum aestivum). World Journal of Agricultural Sciences 5 (2): 159-162.

[67] Toaima S. E., El-Hofi A. A. and Ashoush H. 2000. Yield and technological characteristics of some wheat varieties as affected by $\mathrm{N}$ - fertilization and seed rates. Mansoura University. Journal of Agricultural Science, 25: 2449-2467.

[68] Worku Awdie. 2008. Effects of nitrogen and seed rates on yield and yield components of bread Wheat (Triticum aestivum L.) in yelmana densa district, northwestern Ethiopia. M. Sc. Thesis. The School of Graduate Studies of Haramaya University. Harar, Ethiopia.

[69] Yosef G. H., Kebede T., Senait W. 2011. Achievements of food barley breeding research for low moisture stressed environments of northeast Ethiopia. Barley Research.

[70] Zewdie Bishaw, Paul C. Struik and Anthony J. G. 2014. Assessment of on-farm diversity of wheat varieties and landraces: evidence from farmer's field in Ethiopia. African Journal of Agricultural Research, 9 (38): 2948-2963. 